\title{
FAITH-BASED SOCIALLY RESPONSIBLE ENTERPRISES SELECTED PHILIPPINE CASES
}

\author{
ALIZA D. RACELIS \\ University of the Philippines Diliman \\ Quezon City, Philippines \\ aliza.racelis@up.edu.ph
}

\begin{abstract}
Faith-based organizations (FBOs) have long played a role in international development and are increasingly involved in sustainability initiatives. Since they are motivated by a distinctive set of values, have particular modes of operation and governance, and hold a unique place within communities and the larger society, these organizations are poised to be distinctively successful and sustainable. In the case of the Philippines, the situation is unique in the sense that there are a large number of Christian business leaders and entrepreneurs who put their faith "to the plow." Based on a review of the literature on faith-based social enterprises as well as on an in-depth descriptive analysis of three sample ventures from the Philippines, this study proposes a descriptive framework for their success and sustainability which consists primarily of two elements: a) Christian social capital and b) spiritual leadership.
\end{abstract}

Keywords: faith-based organizations; third sector organizations; Christian social capital; spiritual leadership

\section{INTRODUCTION}

Organizations are being called upon to take responsibility for the ways their operations impact societies and the natural environment. It is no longer acceptable for a corporation to experience economic prosperity in isolation from those agents impacted by its actions. Moreover, we are without a doubt witnessing today a remarkable growth in the so-called "third sector," i.e., in socio-economic initiatives which belong neither 
to the traditional private for-profit sector nor to the public sector. These initiatives generally derive their impetus from voluntary organizations and operate under a wide variety of legal structures, and they represent in many ways the new or renewed expression of civil society against a background of economic crisis, the weakening of social bonds, and the difficulties of the welfare state (D'Amato, Henderson, \& Florence, 2009; Defourny, 2001). Nevertheless, the surge in the creation and growth of such "third sector enterprises" notwithstanding, one could say that descriptive research on their successes and challenges as well as on the factors accounting for their effectiveness and sustainability seems wanting. For example, explanations of the differences between faithbased and secular social service organizations across the globe are largely lacking in the social enterprise literature (Kerlin, 2010).

If enterprises are faith-based, are there any differences in their effectiveness and sustainability? If so, what accounts for these differences? Christian missionaries treading the globe during the $17^{\text {th }}$ century up to the late 1800 s eventually gave rise to Christian humanitarian agencies intent on meeting not only the spiritual but also the physical needs of their beneficiaries. Governments have also opened themselves up to cooperation with the private religious sector, in part because of disenchantment with public programs and an increasingly widespread view that acute social problems have moral and spiritual roots. Acknowledging, therefore, that such problems arise from both unjust socioeconomic structures and misguided personal choices, scholars, journalists, politicians, and community activists are calling attention to the vital and unique role that religious institutions play in social restoration.

Analysis of the outcomes of faith-based third sector organizations is still wanting, however, even though available evidence suggests that some of their services may be more effective and cost-efficient compared to similar programs from secular society and government. These organizations are motivated by a distinctive set of values, have particular modes of operation and governance, and hold a unique place within communities and the larger society. By way of self-selection, their managers are committed to the "cause" rather than simply to maximizing profits or managerial efficiency. For example, the leaders of Economy of Communion (EoC) businesses, which are growing in number all over the world, act in such a way that helping the poor is viewed not as an optional appendage to the religious act of praying but as an expression of spirituality engaging other dimensions of social and economic life (Gold, 2003). This article thus attempts, through the descriptive analysis of selected Philippine cases of faith-based enterprises, to propose a descriptive framework for their success, after which implications for sustainability will be drawn. 


\section{LITERATURE REVIEW}

\subsection{Third Sector Organizations}

Third sector organizations (TSOs) - voluntary, non-profit, nongovernment, people's, community-based, and civil society organizations as well as cooperatives-are growing rapidly in many countries all over the world. One of the defining characteristics of many TSOs is that they are "values-based" organizations, and among them we find an increasing number of economic initiatives called "social enterprises" which bear witness to the development of a new entrepreneurial spirit focused on social aims. Such enterprises may be regarded as a subdivision of the third sector; however, they also set out a process, a new (social) enterprise spirit which takes up and refashions older experiences. In this sense, they reflect a trend, a groundswell involving the whole of the third sector (Nevile, 2009; Defourny, 2001).

We rely increasingly on TSOs to address ever-growing human and community needs with ever-decreasing resources. By "third sector," we are referring to those community-based organizations that operate exclusively for charitable, community-building, advocacy, or educational purposes and are neither traditional for-profit businesses (first sector) nor governmental agencies (second sector). TSOs are expected to remain steadfast in their missions while smultaneously meeting ever-higher standards of performance in a rapidly changing environment. The impetus for their work comes from a specific religious or ethical base and their distinctive accountability mechanism is such that participants genuinely internalize values shared by others within their network, with critiques of their behavior based on those values.

In liberal welfare states such as Australia and the United Kingdom, TSOs concerned with broad public benefit objectives, such as the alleviation of poverty, have been involved in the delivery of social services for many years. Such organizations, however, now play a more central role in doing so than they did thirty years ago. In their case, moreover, value displacement is not an inevitable consequence of reliance on external funding: where there is a conflict of values, TSOs are at times prepared to walk away from external funding sources. Their accountability regime focuses more on intentions, and relies more heavily upon mutual monitoring and reputational sanctioning within a cooperative network of like-minded entities as its characteristic mechanism for achieving accountability (Evans, Raymond, \& Levine, 2014; Goodin, 2003; Nevile, 2009). 
According to EMES (L'émergence des Entreprises Sociales), the defining characteristics of the "ideal type" of social enterprise include:

1. continuous activity producing goods and/or selling services;

2. a high degree of autonomy;

3. a significant level of economic risk;

4. a minimum amount of paid work;

5. an explicit aim to benefit the community;

6. an initiative launched by a group of citizens;

7. decision-making power not based on capital ownership;

8. a participatory nature, which involves the persons affected by the activity; and

9. limited profit distribution (Defourny, 2001: 16-18).

The European definition allows at least some profit distribution due mainly to the inclusion of cooperatives in the definition. Social enterprise in Europe is also viewed as belonging to the "social economy" where social benefit is the main driving force. Indeed, the main organizations in the social economy include cooperatives, mutual organizations, associations, and foundations.

Social enterprise is therefore thought of as something new and distinct from classical business and traditional non-profit activity, combining to different extents elements of social purpose, market orientation, and financial performance (Galera \& Borzaga, 2009). All told, it is possible to agree on the following definition of social enterprises: they are organizations whose mission is to bridge social opportunity into sustainable reality innovatively, effectively, and efficiently (Defourny, 2001).

These enterprises represent a common feature of the European social and economic environment. Although not yet in use in legal texts or other official documents in most countries, the expression "social enterprise" is a useful synthesis for several terms used at the national level, such as "social economic enterprises" (Austria), "sociallyaimed enterprises" (Belgium), "co-operatives with social aims" (Spain), and "social co-operatives" (Italy and Portugal). These organizations are found in almost all European countries but have major differences from those involved in work integration, both as to the number of enterprises and the types of service supplied. Social and community care services provision, for instance, represents a broad field of activity-a significant number of social enterprises have been established to provide new services or to respond to groups of people with needs not recognized by public authorities or who have been excluded from public benefits. Many of these activities were started independently by groups of citizens with 
little or no public support, and eventually received partial or even total funding from state or local authorities after some years as the services provided were acknowledged to be of public interest. Moreover, the resulting dependence on public funds did not seem to eliminate their autonomy completely; indeed, there are many social enterprises that are funded by both public authorities and paying customers, or that combine public funds with resources from donations and volunteers. A growing number of services are also provided by social enterprises that secure the necessary public resources by participating in calls for tenders, thereby competing with other TSOs and for-profit enterprises (Defourny, 2001).

The third sector's motivational distinction shows up mainly in their altruistic concern for the "cause." As mentioned above, managers of TSOs are typically committed to the "cause" rather than simply to maximizing profits or managerial efficiency, a fact central to the conventional analysis of why, in a world of imperfect information and incomplete contracting, there seems to be greater trust in, say, non-profits rather than in profit-seeking corporations: they may not be as efficient, but at least they internalize the "right" goals rather than serve ones merely as a means to profit for themselves. Such a comparative difference shows up even more keenly when the TSO is faith-based-for instance, sentiments of bureaucratic restrictions are usually aired out in meetings of secular TSOs compared to their religiously affiliated counterparts who "do the real work" (the comparative sustainability advantages for the more religiously affiliated organizations shall be discussed below) (Goodin, 2003; Caldwell, 2012).

Among the many TSOs out there, non-governmental organizations (NGOs) have over the past several decades pioneered financing for the poor to help alleviate their poverty and improve their socioeconomic conditions. Defined as the "provision of financial services to lowincome clients, including the self-employed" (Ledgerwood, 1999: 1), microfinance services may include savings, credits, insurance, payments, and social intermediation, and are performed by a variety of institutions such as credit unions, savings and loan cooperatives, commercial and government banks, and NGOs. Many thus view microfinance as an instrument of development beyond being just "banking for the poor"at its heart is the belief that poverty can be reduced and eventually eliminated through provision of credit to those too poor to have access to the formal financial system. Such needs are tremendous, with even the dependence of NGOs on donor financing hindering the sustainability and continuity of their activities. In the case of microfinance institutions (MFIs), however, one can see gradual progress toward sustainable, profitable, and self-funding organizations: they have been able to attract equity and their vulnerability has decreased, sometimes to 
lower than that of commercial banks. For MFIs, the client relationship necessitates an intimate knowledge of the client's business and active collaboration to ensure the client's success. Security, on the other hand, is characterized mainly by collective monitoring as there is a huge client base of individuals who need to be tied to a group or groups (Koveos \& Randhawa, 2004).

All told, the social enterprise movement is growing and gathering supporters across the globe as an innovative approach to business activity, offering disadvantaged and underserved populations a path to human development and economic prosperity. Businesses, governments, and NGOs are increasingly recognizing that their participation in these initiatives can lead to substantial benefits for such populations, all while simultaneously providing opportunities for income generation (Nielsen \& Samia, 2008).

\subsection{Faith-based Organizations}

Christian missionaries treading the globe from the $17^{\text {th }}$ century to the late 1800s were the precursor humanitarians whose sense of Christian duty to "go into all the world and preach the good news to all creation" (Mk. 16:15) inspired their work. Their missionary efforts also gave rise to Christian humanitarian agencies intent on meeting not only the spiritual but also the physical needs of their audiences. In addition to spreading the Gospel, therefore, the first religious aid agencies that developed in conjunction with the Protestant evangelical movements and the birth of missionary organizations were dedicated to assisting ideologically and economically impoverished peoples and bearing the torch for Western civilization. This same sense of duty is present today in modern humanitarianism, the offspring of nineteenth-century Christian thought (Thaut, 2009).

Faith-based organizations (FBOs) are thus "formal organizations whose identity and mission are self-consciously derived from the teachings of one or more religious or spiritual traditions and which operate on a nonprofit, independent, voluntary basis to promote and realize collectively articulated ideas about the public good" (Berger, 2003: 16). They have long played a role in international development and are increasingly involved in sustainability initiatives. Particularly noteworthy as well is their success in effecting sustainable and holistic change in many countries due to their rootedness in the community, the social capital they help produce, and the respect they receive from the people. In many parts of Africa, for example, Christian organizations and agencies have long been involved in development work, driven by charitable impulses, evangelical zeal, and, to some extent, by complicity with the 
colonial machine. Such work began with mission stations that offered schools and health clinics, and which expanded over time beyond education and health care to include agriculture, water supply programs, and many other projects (Thaut, 2009; Moyer, Sinclair, \& Spaling, 2012).

Significant FBO involvement in environmental sustainability work is rather recent, however, although faith communities are taking a growing interest in these issues and engaging in diverse initiatives around the globe. In the United States, for example, the Evangelical Environmental Network and the National Religious Partnership for the Environment are working to influence public policy while engaging local congregations to embrace sustainable lifestyles. In Canada, various Christian denominations collaborate on justice initiatives through Kairos, an organization that works to address eco-justice issues such as climate change and energy. Faith groups are also actively addressing environmental concerns in Sub-Saharan Africa, where an interfaith alliance of Zimbabwean Christians and traditional practitioners has engaged in extensive tree planting projects. The Faith and Earthkeeping Project, under the auspices of the World Wide Fund for Nature-South Africa, promotes environmental protection, conservation, and sustainable resource use at various levels (Moyer et al., 2012).

While they share in many of the attributes, strengths, and weaknesses of secular NGOs, FBOs are distinct in their motivation, modes of operation, and place within communities and society. For instance, they are often firmly and intimately rooted within local communities through their ties to local religious establishments, affording them a high level of trust and accountability. In fact, available evidence suggests that some of their services may even be more effective and cost-efficient than similar secular and government programs. They also tend to adopt an approach that goes beyond basic economic advancement or environmental protection, incorporating the social, environmental, spiritual, and ethical in one complete package (Moyer et al., 2012; Sider \& Unruh, 1999).

FBOs differ significantly from their more secular counterparts across several aspects, including funding sources and preferences, decisionmaking tools, organizational culture, practices, leadership, and staffing characteristics. Some proponents of expanding faith-based social service delivery, for example, argue that religiously-based groups provide more effective social services than secular agencies do because their religious character motivates a supportive and caring attitude on the part of staff and volunteers, one that is transmitted through relationally-based programs aimed at transforming lives (Ebaugh, Pipes, Chafetz, \& Daniels, 2003). They are also particularly strong in effecting sustainability through 
religious and ethical social capital, connectedness to communities, and an integrated approach to development and environment. As such, both benefactors and beneficiaries in general develop a sense of individual and community responsibility for the correction of social ills (Olasky, 1995; Moyer et al., 2012).

A good number of faith-based social service programs have been categorized as such based on two basic dimensions of religiosity:

- environmental elements, including affiliation with a church or denomination; display of religious objects, images, and literature in the space where the program meets; selection of board members and/or staff based on their religious beliefs; and a mission statement that has explicitly religious references; and

- active religious elements, that is, those that involve the direct communication of a religious message to clients, or client involvement in specifically religious activities (Thaut, 2009).

Another typology of FBOs is conceptualized as a continuum of religiosity ranging from faith-saturated to secular organizations, with faith-centered, faith-related, faith-background, and faith-secular partnership as degrees between the two extremes. The characteristics of religiosity that are used to place an organization on the continuum are the following:

1. mission statement;

2. religious purpose in the founding;

3. religiousness of the controlling board, senior management, and staff;

4. affiliations with external religious agencies;

5. financial support from religious sources;

6. religious content of the program;

7. connection between religious content and outcomes; and

8. religious environment (e.g., name, building, religious symbols) (Ebaugh et al., 2003).

FBOs are also much more concentrated in their service offerings than their secular counterparts. They play an important role, however, through their emphasis on transitional assistance, their multi-service orientation, and their reliance on interventions that utilize their unique strengths. The unique organizational structure of FBOs may thus offer both efficiency and effectiveness advantages over secular service 
providers and which have implications for long-term sustainability. First, FBOs may be more efficient at delivering some social services, with avenues for such an advantage including the role of churches and volunteers. Churches, being the most common institution in many local communities, have existing infrastructure and network relationshipsbuildings, human resources, community connections-that could be utilized for the delivery of social services. Christian congregations, for instance, are well positioned to address the multi-service needs of the poor because of their strong networks within the community. FBOs also have access to volunteers, whose role in the service provision of these organizations is substantial-such "low-cost" labor may enable FBOs to offer more services or allot more time to each beneficiary compared to other providers. Second, the defining characteristic of these organizations - their reliance on faith-may make them more effective by leading them to employ either different methods of service delivery or the same methods but with more intensity compared to secular service providers (Graddy \& Ye, 2006).

Christianity has played a major role over the centuries in a special way. Its principles and missionary efforts, for instance, have been central in the development of humanitarianism. Agencies associated with the Christian tradition comprise a prominent and growing portion of international humanitarian organizations, and Christian views of love and care for one's neighbor are fundamental to a Western concept of humanitarianism, making Christian faith-based agencies major global players in the field (Thaut, 2009). These organizations typically see their work as a ministry or calling, causing them to behave differently than other service providers. Due to their sense of mission, they are more willing to make long-term commitments to service recipients and continue providing service until changes occur. As such, these FBOs are more likely to rely on mentoring and on one-on-one relationships in which a person is encouraged, challenged, and taught how to do things. They are more adaptive and willing to conform services to an individual's needs in contrast to a governmental program that insists on conformity for all. Such findings are consistent with the most oft-cited advantage of FBOs-their potential for a life-transforming effect on service recipients. The implication for long-term sustainability, therefore, is as follows: if congregations can foster individual transformations that lead to better problem-solving skills, increased self-respect, and healthier family dynamics, then these attributes will lead to greater self-sufficiency (Graddy \& Ye, 2006).

After having discussed whether and why religiously affiliated organizations are perceived to be better than their secular counterparts at providing assistance services, we turn our attention to faith-based 
TSOs themselves. In certain Western countries as of late, religiously affiliated organizations have focused more on smaller-scale solutions to pressing social problems of poverty, homelessness, addiction treatment, medical care, and human rights. As we have seen above, they are not necessarily bound by the same ideological and practical expectations for results, accountability, legal recognition, and networking as their secular counterparts are, taking their cues instead from denominational ethics and institutional practices. As a consequence, religiously affiliated assistance programs (often) fall outside, if not fitting uneasily within, prevailing institutional logics, thereby enabling them to carve out a productive niche for themselves. Staff and supporters of such smallerscale entities contend that their value and effectiveness derive precisely from their ability to address the gaps-and even negative consequencescaused by conventional development projects (Caldwell, 2012).

Faith-based social enterprises such as those discussed here have a special role to play in alleviating poverty, creating empowerment, and establishing entitlement at the grassroots level of socioeconomic development. The endpoint for many of them is a participatory socioeconomic transformation in which the non-competing poor and underprivileged cooperate with each other, and where meaningful relations are created between the resourceful and those in need to enhance community well-being (Choudhury, Hossain, \& Solaiman, 2008). Thus, rather than be some quick-fix solution, they require easily accessible, low cost, and amenable funds and technology that can be sustained in the long-term.

In addition to the social capital inherent in FBOs, the spirituality of the leader has also been discovered to have a critical impact on social enterprises. The importance of values and the role of the leader in their infusion within organizations cannot be ignored since the institutional leader is an expert primarily in the promotion and protection of values, defined as what the organization essentially stands for and that which must be promoted by its leaders to ensure institutional integrity (Teehankee, 2012).

The aim of regeneration for developing sustainable communities appears to have been achievable through FBOs as well. The values of TSOs in providing a voice for under-represented groups; campaigning for change; creating strong, active, and connected communities; and promoting enterprising solutions to social and environmental challenges have been recognized-to be more precise, the role of the third sector as a "driver" for building sustainable communities has been stressed: the third sector-and social enterprise in particular-can be an engine for regeneration. Indeed, a highlight here is the activity of the third sector 
in delivering environmental improvements and meeting environmental challenges - it seems to have a clear role in increasing voluntary activity toward environmental improvement, often building a sense of community pride and ownership in the process. Faith-based TSOs are thus poised to deliver neighborhood regeneration and civil renewal which in turn are necessary for sustainable regeneration and the fostering of sustainable communities, especially since it has been argued that faithbased social service delivery provides more effective services compared to secular agencies (Ebaugh et al., 2003; Smith, 2010).

It has also been argued that religion can improve mental, physical, and spiritual health as well as resolve a number of social problems, and that FBOs, compared to government and secular service providers, can offer a more holistic approach to meeting individuals' needs by providing caring staff and supportive networks. Faith-based social service organizations generally allow both care providers and beneficiaries to develop a sense of individual and communal responsibility when approaching social concerns. Christian organizations, moreover, emphasize relationships arising from a business encounter in a special way because of the belief that they are responding to the most basic of Christian calls: to love one another and to be a gift to each other (Clerkin \& Grønbjerg, 2007; Gallagher \& Buckeye, 2014).

For Roman Catholic faith-in-action, one integrative finding involves the Roman Catholic perspective on human life, which has been shown to inform the entire organization. A Roman Catholic businessperson is obliged to struggle for business success while serving the community and trying to live as a good Roman Catholic in a world of temptations and contradicting realities. In addition to necessary skills in communication, numeracy, critical thinking, and problem solving, good Roman Catholics in FBOs abide by a "Catholic moral center" which has come to form part of their core competencies (Del Rosario, 2015). As shown in various case studies, the downtrodden are viewed as worthy of support due to their membership in the human family; their misfortunes, relative disadvantages, and previous wrongdoings become meaningless compared to the spiritual gifts of being created by God in the divine image and likeness and of having been bestowed with an immortal soul. Those who are less fortunate are invited to eat at God's table as part of the promise that the meek in spirit shall inherit the earth (Matt. 5:5).

Beyond these outcomes, however, the more important finding is the empowerment provided by social capital. In this context, the Roman Catholic faithful embrace the deeply-rooted concern for each other that exists within the impoverished collective, a concern that results in the sharing of meager resources to enhance mutual survival in times of 
greatest need; such an ethic may have as its origin a form of reciprocity that mirrors the motivations of Roman Catholic clergy and volunteers who work for the poor. Indeed, it was discovered that lending, borrowing, and trading within impoverished consumer subpopulations was designed to smooth out peaks and valleys in the availability of perishable items or emergency requirements. Instead of allowing food to go to waste during periods of excess, for example, an individual may share what she or he has to engender a feeling of obligation that is essential for reciprocal relationships (Hill, 2006).

\subsection{The National Religious Partnership for the Environment}

The religious community's response to increasing concerns about the relationship between humans and nature has been vast and varied. In some cases, it has been simply to form bodies that will explore ways of raising environmental consciousness, such as when astronomer Carl Sagan; the Very Rev. James P. Morton, president of the Temple of Understanding; and Paul Gorman, vice president of public affairs for the Cathedral of the Divine in New York City, drafted an open letter to the religious community in 1990 in an effort that led to the 1992 formation of the National Religious Partnership for the Environment (NRPE). Representing a range of Christian and Jewish communities in the United States, the NRPE seeks to incorporate environmental concern into religious life on various levels. It is comprised of four major organizations that together serve more than 100 million Americans-the United States Conference of Catholic Bishops (USCCB), the National Council of Churches of Christ (NCCC), the Coalition on Environment and Jewish Life (COEJL), and the Evangelical Environmental Network (EEN) - and engages scholars in the task of exploring and publicizing the connections between religious traditions and the environment through conferences and publications (see http://fore.yale.edu/religion/ christianity/projects/nrpe/). The COEJL, in particular, builds a strong case for the complementary roles of religion and science:

\footnotetext{
"Stewardship is a way of seeing the world that comes out of our most ancient religious traditions and feeds directly into our most contemporary scientific understandings. There is in fact a powerful, even wondrous link between the mystical and the statistical.... Religion and science alike agree that there is a profound integrity to the natural order, a marvellous ecological complexity that even now, with all our growing understanding, is beyond our comprehension. The serious scientist is no less in awe of that integrity, of that complexity, of that order, than the most pious person of faith," says its study and action guide To Till and to Tend. (Baker, 1996)
} 
The NRPE has been active in distributing "creation care resources" to congregations as well as lobbying in the public policy arena. Matthew Fox, an Episcopal priest and founder of the University of Creation Spirituality, has argued for an end to dualism in which human beings and nature are seen as separate. He posits instead a "creation-centered spirituality" which overturns the usual Christian emphasis on the fall and redemption. The Episcopal Cathedral Church of Saint John the Divine in New York City, which is also the home of the NRPE, has led the way in the greening of Christian liturgy; other Christian worship services have been altered as well to include a more explicit emphasis on nature. For instance, in addition to sponsoring the Gaia Institute (whose purpose is to explore and expand the Gaia hypothesis-that the Earth is a living, self-regulating entity), the Episcopal Cathedral Church now blesses animals on the Feast of Saint Francis (Hill, 2000).

Aside from the NRPE, the religious environmental movement spurred other significant institutional innovations such as the development of new faith-based environmental organizations. Many of these initiatives began in response to official environmental statements made by national religious assemblies, and alongside the corresponding emergence of national ministries. Indeed, the literature indicates that many denominations and FBOs have made significant inroads in promoting religious environmentalism at the individual and congregational level. Moreover, while many of the faith-based environmental initiatives were responding to official statements at the national level, other faith-based groups emerged to address local environmental concerns. Stewardship does truly serve as the conceptual common ground across these groups (Hand \& Crowe, 2012).

\section{FAITH-BASED SOCIAL ENTERPRISES: THE PHILIPPINE CASE}

Large portions of East and Southeast Asia are in the throes of a historically unprecedented upsurge in religious observance and association, though many analysts have emphasized the influence of postcolonial secularisms, neoliberal disciplines, and ascendant civil societies in this religious resurgence. Scholars from many disciplines and approaches have pointed out a vast array of factors that may have affected the current interest in workplace spirituality and religion, including demographic and religious changes in society, overall improvements in certain nations' standard of living, and a variety of transformations in the workplace itself. The Philippines, where 85-90 percent of the population consider themselves Roman Catholic, is no exception: the country and its culture subscribe to the morality encapsulated in 
the Decalogue, especially the Seventh and Tenth Commandments (concerning respect for property) as well as, to a lesser degree, the Eighth (referring to trustworthiness) (Hefner, 2010; Hicks, 2003; Sison \& PalmaAngeles, 1997). Business practices in the Philippines are thus largely influenced by Christian faith.

Drawing from the wellsprings of the social doctrine of the Roman Catholic Church, Philippine business in general advocates a moral and spiritual vision of society which counts as its basic principles integral development, social justice, a preferential love for the poor, an attitude of respect and responsible stewardship over nature as material creation, and the non-espousal of any particular ideology, be it liberal capitalism or Marxist collectivism. Consequently, it admonishes all Church sectors, among other things, to work actively for the end of the manufacture and trade of arms; to address crucial issues such as agrarian and industrialization concerns, the exploitation of women, children, and migrant workers, foreign debt, international trade, etc.; and to undertake collections for the immediate relief and rehabilitation of the poor and the needy. There have always been problems, however, in the exercise of one's faith, as well as challenges in how it could influence one's own behavior and profession (even though majority of the population declares itself to be Roman Catholic). Nevertheless, a good number of Filipino Roman Catholics/Christians have given ground to the demand that religion resonate with the needs and desires of ordinary believers, especially the poor and marginalized (Sison \& Palma-Angeles, 1997).

Just like in other developing or underdeveloped nations, and with poverty as a major social pressure point, government capacity to deliver social equity in the Philippines is stretched, and so business is called upon to take up the slack. Corporate philanthropy has turned out to be a way to augment the government's efforts in addressing pressing social problems such as destitution, joblessness, homelessness, and hunger. The solutions to such concerns in the Philippines are ultimately to be found in:

- countryside and rural infrastructure;

- quality basic education for the children of the poor and in Muslim areas, and especially for women;

- cash transfers to the poorest of the poor;

- primary health services;

- microcredit and microenterprise programs;

- technical skills training for secondary school students; and

- social housing such as that provided by Gawad Kalinga (Habaradas, 2013; Racelis, 2012). 
As a predominantly Roman Catholic country, the Philippines also has a good number of Christian educational institutions-and Roman Catholic business schools in particular-that have produced businesspersons who continuously try to succeed in business while upholding Roman Catholic principles. Students in these institutions learn how to live a morally good life and make the right business decisions for the rest of their professional lives; they are ready to question the status quo, stand on principles, and transform Philippine communities. In their faith-based management courses, the commitment and vision is to produce managers and business leaders who have the passion and commitment to help millions of Filipinos out of poverty and into lives of dignity and well-being. From 2007 onwards, and with the United Nations' Principles for Responsible Management Education (UN-PRME) as guidelines, specific business schools were thus presented with the opportunity to deepen further their commitment to management education for social responsibility (Teehankee, 2012; Del Rosario, 2015).

The next subsections take up three case studies of socially-oriented enterprises created by prominent Roman Catholic or Christian businesspersons in the Philippines, namely the highly successful Gawad Kalinga (literally, "give care" or "sharing and caring"), Bangko Kabayan (literally, "national solidarity bank"), and Rags2Riches, Inc., a social enterprise that evolved out of the efforts of the Simbahang Lingkod ng Bayan (literally, "the Church at the service of the community"), a Jesuit social apostolate organization.

\subsection{Gawad Kalinga}

Roman Catholic entrepreneur and social worker Mr. Antonio "Tony" Meloto received the Magsaysay Award for Community Leadership in 2006 for his work as the founder and primary mover of his brainchild, Gawad Kalinga (GK), an organization that has brought together a massive army of volunteers who work in bayanihan [literally, "in solidarity"] to bring about change and restore the dignity of the poorest of the poor. Although it was not originally conceived to solve the urban housing problem, GK is now known largely because of its success in mobilizing donors, volunteers, and intended beneficiaries to build beautiful and colorful houses in thousands of communities all over the Philippines. GK is present in almost every province in the country and has affected 60,000 families across over 2,000 communities, with 16 Area Coordination Teams on the ground going to where help is needed the most (Gawad Kalinga, 2014; Habaradas, 2013). 
Beyond building houses, GK has also initiated self-sustaining programs that have improved the lives of more than 200,000 families (and counting) throughout the country since the mid-1990s. This has prompted observers to ask about the formula for its continued success. In Gawad Kalinga, the most important innovation is a shift in the paradigm of what community development ought to be. Instead of looking at members of poor communities as passive actors (i.e., as mere recipients of donations or beneficiaries of support programs), GK considers them to be active participants in the development process. The organization has succeeded in creating an image that appeals to donors, volunteers, and other stakeholders-fashioned as a nationbuilding movement, GK seeks to build a nation "empowered by people with faith and patriotism," one that is made up of "caring and sharing communities, dedicated to [eradicating] poverty and [restoring] human dignity" (Habaradas \& Aquino, 2010).

The GK way thus takes a holistic approach that is sensitive to cultural values and social structures. It loves the poor and honors the rich who care for them. It does not condone corruption but engages all politicians who want to follow their brand of honest development which is their antidote to corruption. It follows the old-fashioned Filipino philosophy called "bayanihan"or "cooperativism." GK aims to restore the dignity of men and women, and at its core are those thousands of volunteersyoung men and women, students, captains of industry, retired business persons-who offer "sweat equity" to build homes literally for the poor. Being a hero for others and leaving no one behind are central to the GK paradigm and ethic of simply helping one's neighbors (Meloto, 2009; Brillantes \& Fernandez, 2011).

GK is a faith-based initiative and has become an operative model of development that can complement research, training, and extension work. Their values formation is based on universal human values that focus on caring, sharing, and learning how to become a brother's keeper. The initiative, in fact, has gone beyond providing a roof for the homeless: research shows how GK is transforming people's lifestyles, giving hopes and aspirations that result in greater self-reliance (lower, if not eradicated, incidences of scavenging and mendicancy), disciplined habits (lower spending on vices such as alcohol and gambling and greater spending on food), and improved health (lower incidence of disease and less spending on medicines) among their residents. Moreover, GK has also provided a framework for active citizen engagement in the process of improving quality of life. Active citizen participation is central to addressing basic problems such as corruption and an alarming decline of trust in institutions, problems besetting nations today but most especially developing ones like the Philippines (Brillantes \& Fernandez, 2011). 
This case highlights the ability of timely and values-based actions of entrepreneurial leaders in socially legitimated positions as well as the enabling of social conditions to bring about faith-based management in business organizations. Faith is expressed in GK's understanding of the root cause of poverty as not simply the absence of money but as an absence of shared values, of a sense of community and higher purpose. The case likewise showcases the necessity for leadership to fulfil its role as protector and promoter of values. For GK, their "good governance" ideal revolves around transparency, accountability, participation, rule of law, equity and social justice, sustainability, and continuity. Indeed, given chronic poverty in the Philippines, the entrepreneurial leadership of individuals like Mr. Meloto can provide far-reaching benefits to this developing nation (Teehankee, 2012).

\subsection{Bangko Kabayan: An Economy of Communion Bank}

Faith-based organizations tend to attach great importance to maintaining and enacting their ethos or values. This could be expressed, for example, in the realm of contracts and resources-the ability to secure voluntary resources, particularly through faith communities, plays a key part in enabling organizations to retain some autonomy and continue pursuing their own values, thereby achieving sustainability (Buckingham, 2012). For enterprises created and led by faith-enabled leaders, therefore, the spiritual and economic dimensions of life are visibly and intrinsically bound together, such as in the case of the Economy of Communion model of Chiara Lubich, founder of the Focolare Movement, where economic facts are interpreted as substantive proof of God's intervention in human life.

The most recent development in the economic vision of the Focolare Movement (an ecclesial community present in the Roman Catholic Church since the 1940s), the Economy of Communion model emerged in Brazil in 1991 and aims to offer a global Christian response to the pressing problems of poverty and injustice by challenging the underlying ethos of business and finance. It involves business people animated by Focolare spirituality who set up a new kind of enterprise based on Christian ethics. Operating within the free market and abiding by the business regulations and standards therein, such enterprises put the Focolare vision into practice primarily by dividing profits into three parts: one part goes to the poor, another to re-investment, and a third to the formation of others in this spirit. These businesses also try to apply certain ethical guidelines which mirror the "seven aspects" of spiritual life that underpin Focolare spirituality. Having been likened to the rainbow, these seven aspects speak of love as follows: 
1. love leads to communion;

2. love is not closed in on itself but spreads according to its nature;

3. love elevates the soul, which is union with God in prayer;

4. love heals;

5. love gathers people together in assembly;

6. love is the source of wisdom and enlightens us; and

7. love gathers many into one, and this is unity.

In the ten years or so after the emergence of the EoC model, 761 businesses from all economic sectors have become EoC enterprises: 246 in Italy, 232 in the rest of Europe (60 of which are in Eastern Europe), 176 in Latin America, 45 in North America, 36 in Asia (including Bangko Kabayan in the Philippines, which will be discussed below), 15 in Australia, 9 in Africa, and 2 in the Middle East. The majority are small and medium sized companies, but ten of them have over 100 employees each. 194 are engaged in production/manufacturing activities, 161 in commerce, and 327 in services (Gold, 2003).

The general ideas of the EoC model have been very positively received, including in the Philippines where Bangko Kabayan is flourishing as an EoC bank. Ms. Teresa "Tess" Ganzon met the Focolare Movement in 1968 and has been an active member since. In 1991, she and her husband Francis, who had a one-unit rural bank, decided to adhere to the EoC project and have since grown their enterprise to the present 18-branch institution, particularly serving the micro, small, and medium entrepreneurs (MSMEs) of Batangas and the other provinces of Southern Luzon in the Philippines. Indeed, this experience of Bangko Kabayan along the principles of EoC has been shared in various international fora, and Tess has served as a member of the International Commission on Economy of Communion since 2008 (Ganzon, 2013).

Just like other EoC enterprises around the world, Bangko Kabayan embraces the following mindset:

I believe that there is a condition, mostly spiritual, that impedes us from feeling secure and self-sufficient without having to depend on anyone and anything. When we no longer feel fragile and in need of help, when a bank account and secure job give us (or promise us) self-sufficiency and independence from others, then we are no longer those poor that the Gospel calls "blessed." This dimension of poverty depends on and is linked to all the other beatitudes. Only he who is pure, meek, a builder of peace, [and] persecuted for justice, can first understand and then live life with the blessed poverty described in the Gospels. The entrepreneur, too, is called to live this kind of poverty, if he wants to be an EoC entrepreneur. This poverty is 
not only spiritual detachment but much more. There is detachment from his role, from power, and perhaps from certain comforts, even when all of his colleagues consider them normal. Then, there is concrete detachment from money, when, at the end of the year, he gives part of his profits to further the goals of the EoC. These donated profits, which are not put in the bank, make him more vulnerable (therefore, these choices are always delicate in a business-not finding oneself a burden for others is a form of love and of responsibility). These donated profits put him in conditions of greater dependence and vulnerability, especially in difficult moments and in crises. (Bruni, 2010)

\subsection{Rags2Riches}

Conceived in 2007, Rags2Riches, Inc. is a faith-based social enterprise that evolved out of the efforts of Simbahang Lingkod ng Bayan [literally, "the Church at the service of the community"], a Jesuit social apostolate organization. Those who conceptualized the project wanted from the very beginning to help the women of Payatas, ${ }^{1}$ many of whom were mothers who stayed at home to take care of their children, earn more income and live more dignified lives.

Taking advantage of their time at home and the garbage pile surrounding them, some of these women began to weave cloth scraps into multi-colored doormats, rags, and rugs for use in Filipino homes. It was a trend that soon grew into an informal cottage industry of rugweavers, its products made mainly from upcycled cloths and scraps discarded from factories. Coming to their aid, Rags2Riches helped the women improve the quality and style of the rugs, transforming the unattractive multicolored pieces into appealing monochromatic fabrics.

The market's response to the elegant and stylish rugs was remarkable: the first few bazaars of Rags2Riches were sold-out and garnered a lot of positive feedback. Moreover, the women now directly supply a few upmarket boutiques in Metro Manila instead of selling their products through middlemen, who would purchase each rug for one peso (approx. U.S. \$0.02) and then turn around to rake in twenty-five times that amount. Each rug now sells for about PhP 50 after Rags2Riches cut out the middlemen and taught the women how to improve their design and produce high-quality rugs.

Near the end of 2007, the Rags2Riches team decided to add more value to the current product line by integrating a designer angle. Two of

${ }^{1}$ Located in the north of Metro Manila, Payatas is one of the biggest dumpsites in the Philippines and a residential area for hundreds of Filipino households. 
the members got in touch with Rajo Laurel, a famous Filipino fashion designer, and the team shared the ideals of Rags2Riches with him over an informal dinner. On that very same night, he transformed ordinary rags into elegant fashion pieces; by the very next day, he provided prototypes, and in less than four months, Rags2Riches was able to grow the initial capital by almost 400 percent.

Such results inspired the team to turn the social business enterprise into a formal corporation. Thus, from 20 housemothers, it is now helping at least 400, and in 2009 won the Business in Development Global Competition award. And while expansion resulted in engagements with other nearby communities, Rags2Riches ensured throughout it all that its products were one hundred percent consistent with their values, and that all materials were upcycled and thus "eco-friendly" (e.g., organic materials that did not use harmful dyes or chemicals). The women of Payatas-and of other communities as well-have clearly become empowered and enriched (Arnaldo, 2008; Cantera, 2009; Pelejo, 2012).

This case highlights the good effects that can be achieved by the mere desire to serve people and communities based on faith and mission. Rags2Riches aimed to improve the livelihood outcomes of the poor. Apart from meeting the "triple bottomline"-people, planet, and profits, it sought to exert a positive influence on the market, on the communities it works with, and eventually on the world. Indeed, the company has since spun off other similar faith-based social enterprises, including on Culion, a small island in Palawan, Philippines. Xavier "Javy" Alpasa, S.J., who used to serve as president of Rags2Riches, Inc., is committed to helping and training the students of the Loyola College of Culion, one of the most financially challenged Jesuit schools in the country, so that they may benefit from social enterprise. Fr. Alpasa is determined to promote social entrepreneurship as a good solution for society's ills via the triple bottomline, viz. caring for people, planet, and profit through positive influence (Pelejo, 2012; Pastores, 2010).

For Rags2Riches, patent in their origins is that Jesuit passion and spirituality whose social apostolate moved them to come to the aid of these women so that they may earn more, take better care of their health and well-being, and lead lives worthy of their innate dignity. As Teehankee (2012) carefully notes, the importance of values and the role of the leader in their infusion stand out in a special way indeed in Roman Catholic educational institutions in the Philippines. 


\section{PHILIPPINE FAITH-BASED SOCIAL ENTERPRISES: A PROPOSED THEORETICAL FRAMEWORK}

Fissures exist within the Philippine economy, especially in the gap between the rich and the poor-income distribution has remained practically unchanged since 1985 , when the upper 50 percent of families enjoyed 82 percent of the income; their share became only slightly lower at 80 percent in 2009. The theme, therefore, of the medium-term development plan of the present Philippine government and World Bank country report is inclusive growth. This reflects both the glaring income disparities which have persisted among Filipinos and the remedial measures to calm down this social volcano. Vibrant local communities, which are generally able to surf over threats and have the unique advantage of combining economic imperatives with social benefits, thus continue to be a source of hope. The same can be said for values such as self-transcendence and conservation which have formed over many years the basis upon which Filipino leaders have exercised social responsibility. Well-managed corporations also manifest trust in God in their social initiatives, such as in the proper treatment of employees (including job security and profit sharing), transparency, and good governance. Indeed, the Christian faith of employers-translated into the practice of social justice and the firm belief that both employees and capital equally deserve a share in the fruits of the economic enterprisehas in some cases led firms to commit generously to profit-sharing over several decades (Loanzon, 2012; Manalastas, 2007; Chan, 2015).

Religion and FBOs, in fact, typify the challenges that TSOs face as the public seeks to understand accountability. FBOs, for instance, tend to be more preoccupied with promoting their sacred mission than with adhering to accountability templates associated with the commercial and public sector. Their work is motivated by religion and/or ethics, their accountability mechanism is based on internally shared values and critique (Goodin, 2003), and they tend to adopt an inward focus that is not always compatible with the outwardly focused values of civic society. The accounting and accountability literature thus shows that account-giving in religious settings very often tends to be motivated by factors that fall outside standard commercial and public frameworks for accountability (Hardy \& Ballis, 2013).

Faith indeed leads certain business leaders to feel that it is their obligation to give the fruits of God's blessings back to His people, particularly since everything comes from Him and He continues to care and provide for all. In the case of EoC businesses, a radical claim at the heart of their enterprise is that people can grow spiritually and in union 
with others through the most basic and common of business practices, although business cannot do this by itself. Unlike other value-based movements that emphasize corporate social responsibility, business ethics, corporate citizenship, or social entrepreneurship, EoC is a movement deeply rooted in a cultural soil with rejuvenating spiritual sources. These enterprises are created and run by those who believe that one can truly see and be "Christ among us" through daily work and the conduct of business.

The great adventure of EoC participants, therefore, is to create a community of businesses that expresses a spirituality of unity. In contrast to an economy dedicated to profit-seeking above all else, the economy to which these companies commit themselves is one that manages work and pursues profits as means of expressing solidarity with co-workers, customers, suppliers, the community, even competitors, and especially with the poor. Therefore, while they are interested in doing well and generating a profit through prudent choices and good fortune, the owners of these businesses have a vision of being good by offering goods that are truly good and services that truly serve (Manalastas, 2007; Gallagher \& Buckeye, 2014).

In light, then, of the Church's divine mandate as an institution meant to address the needs of the "little ones," a realization is being made about the social mission of religious institutions and the role of churches in the economic rehabilitation of the poor. The Church in Africa, for example, has contributed to an enabling environment in which the plight of the poor can be addressed: it has played roles in building the nation, guiding character formation, and providing social services such as schools, clinics, hospitals, and agricultural extension services (Kwarteng \& Acquaye, 2011). Untapped social capital that can be harnessed for rehabilitating the poor, which requires closer collaboration and linkages among religious institutions, the state, and other development practitioners, has been discovered as well in other studies. Being the "light of the world," the Church indeed typically provides an alternative vision for humanity.

The ethnographic study by Hill (2006), for instance, also discerned a special kind of social capital at work in selected Roman Catholic social initiatives. It is evident that the Roman Catholic faithful embrace that concern for the other that is found even among the poor, a trait that supports the collective during times of hardship. In the Philippines, for example, social capital is a means of bonding within vernacular communities, bridging socio-economic divides, and linking these communities and distinct groups with official institutions, civil society, and the market. It manifests basic principles of Roman Catholic social teaching: human dignity, solidarity, and subsidiarity. Thus, overwhelmed 
by turbo-capitalism, countries like the Philippines need to cultivate social capital to survive and flourish (Loanzon, 2012).

Another clear role of faith for business leaders is the potential for their spirituality to bring a workforce or organization together, for a basic workplace spirituality can usually serve as the common ground for a new work community (Hicks, 2003). In fact, spirituality especially on the part of the founder/director has been shown to be of critical importance in the conduct and eventual successful outcome of a faith-based social business. There is growing evidence, moreover, that executives' personal spiritual tradition deeply informs and shapes their leadership through: 1) a sense of leadership as a calling, 2) the desire to integrate deeply held personal values with the leadership role, and 3) spirituality as a source of courage when facing daunting challenges (Delbecq, 1999). Mitroff and Denton (1999) found that individuals and organizations with a strong sense of spirituality are far less likely to compromise their basic beliefs and values, and their data even suggested that spirituality may serve as a possible antidote to leaders' unethical behavior. The study by Johnson (2008), which examined the role of spirituality in ethical decision-making, seems to show that leaders' faith and spirituality move them to look beyond short-term solutions and to consider money as something secondary. Such an outlook imbues most of their customers with a feeling of trust, and leads them to view the way these companies do business as so radically different such that they really enjoy working with these executives over the long term, which obviously has implications for sustainability.

Based on the data and descriptive analyses mentioned above, this study proposes a theoretical framework in Figure 1 below, followed by a brief description of each component.

FAITH-BASED SOCIAL ENTERPRISE

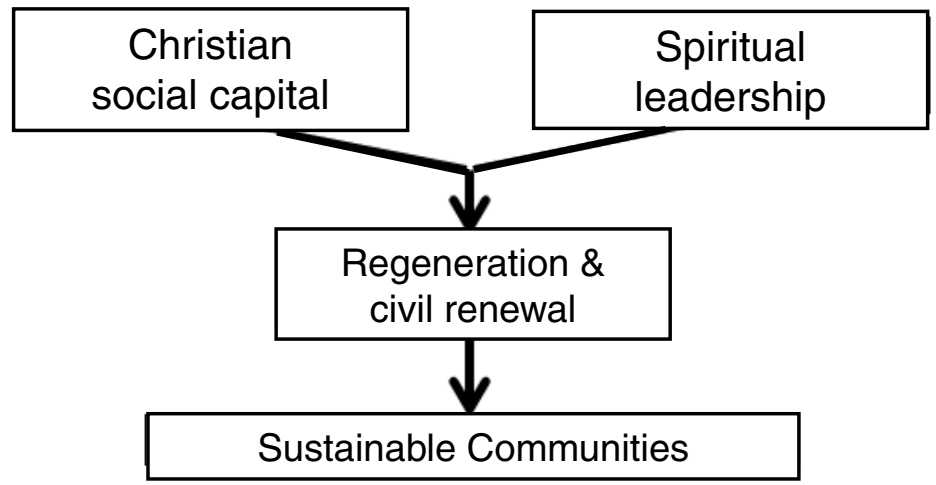

Figure 1: Faith-based Social Enterprise 


\subsection{Christian Social Capital}

Literature and empirical studies reveal that high levels of social capital

- reduce poverty,

- increase health and well-being,

- limit crime rates,

- increase economic productivity,

- improve the quality of public life,

- intensify political participation, and

- increase the efficiency of institutions and administration.

Faith-based social capital is given a lot of special importance. Religious organizations, for instance, provide this valuable resource in considerable amounts-beyond the benefits accruing to the members of churches and religious organizations themselves, it has been shown that many religious organizations' activities also aim to serve the common good, thereby benefiting society as a whole (Traunmüller \& Freitag, 2011). Faith-based social enterprises have also been successful in effecting sustainable and holistic change in the communities they serve, due in part to their ability to bridge socio-economic divides and an integrated approach to development and environment.

The following are characteristics of social capital as seen in the particular case studies above:

1. a participatory nature which involves the persons affected by the activity;

2. Christian proponents who embrace the deeply-rooted concern for one another which results in the sharing of meager resources to enhance mutual survival in times of greatest need (Church teachings on human dignity, solidarity, and subsidiarity have been particularly helpful in this regard); and

3. a Church that typically provides an alternative vision for humanity because it is an institution that is divinely mandated to be the "light of the world."

Indeed, the faith-based social enterprise's social capital is one that can be harnessed for rehabilitating the poor because it enables closer collaboration and linkages among religious institutions, the state, the market, civil society, and other development practitioners. 
A culture like Gawad Kalinga's, for instance, is shot through with a Christian valuation of human life: it believes that restoring human dignity is integral to eradicating poverty. By taking the poorest of the poor out of a slum environment and providing for their basic needs (land, food, and homes for security), GK overcomes the sense of helplessness that poverty brings and helps transform their residents' lives by providing the sweat equity needed for building their new homes and community infrastructure. This in turn brings peace and cooperation to the community and helps build the bayanihan [literally, "community solidarity"] spirit among the residents. For EoC enterprises, on the other hand, giving profits for use outside of the business is an act of great poverty on behalf of the entrepreneur. It almost seems to go against nature, even, as entrepreneurs have the instinct to build their businesses. But this giving has great ethical and spiritual value, one that has led to the term "the culture of giving." It is a business model that is permeated with the Christian values of solidarity and care, principles highly encouraged among EoC practitioners and that have been referred to as "seeing things together," "humanizing" the economy, creating a "communion of goods," and trusting in Providence (Habaradas, 2013; Gold, 2003).

\subsection{Spiritual Leadership}

Values influence organizations given that leadership attitudes are influenced by discreet spiritual values and that spirituality is an important part of leadership practice. In most cases, faith leads business leaders to feel that it is their obligation to exercise greater care over human resources and a keener social responsibility. Theirs is a spirituality that has the power to bring about greater solidarity and unity in the work community. Such leadership spirituality also contributes significantly to advancing the sustainability project by facilitating engagement with deep questions about values and ethics, providing moral leadership and critical voices, influencing behavior, and introducing hope to demoralized efforts. In the Philippines, for example, meaningful social initiatives by businesses are driven by corporate values and leadership, and adopt a relational approach in dealing not only with community members or beneficiaries but also with various stakeholders (Habaradas, 2013; Moyer et al., 2012).

In the case of Gawad Kalinga, where the "Roadmap to End Poverty" begins with dignity restoration and moves on to community empowerment, access to mainstream opportunities and basic services, and eventually to character building and good citizenship, the strategic intervention is to provide values formation. The conduct of regular community values formation and leadership sessions helps transform the poor into organized and self-propelled collectives driven by universal 
values of integrity, stewardship, servanthood, and solidarity (Gawad Kalinga, 2014). For Bangko Kabayan, the entrepreneur is a builder and an innovator by vocation, and the business leader betrays her social function if she becomes a seeker of income and position or a consumer of luxury goods. Such are the fruits of that original charism of the movement's founder and leader whose life experiences taught her profound perceptions of who people were in relation to God, to others, and to their place in the cosmos (Gold, 2003; Bruni, 2010; Caldwell, 2012). In both these cases, therefore, one sees that faith organizations present remarkably successful alternatives for enlisting and sustaining grassroots support in ways that create permanent communities of caring. This is borne out of Filipino leaders' unique values such as family closeness and solidarity, politeness, hospitality, gratitude, social acceptance, economic security, trust in God, and a firm conviction that a person's ultimate accountability is to his Creator, values that seem to be more closely associated with sustainability than those held by more secularly-led organizations (Manalastas, 2007).

In the case of Rags2Riches, the spiritual leadership of Fr. Alpasa moved him to continue providing the women of Payatas with earning opportunities through designer bags and fashion pieces made out of cloth scraps. He was motivated to create change where he was, and considered the beneficiaries of the social enterprise as "partners" on an equal level with the so-called "executives" of the firm. Since then, Fr. Alpasa has continued to promote social entrepreneurship as an alternative solution to social problems, and even created a new social enterprise after being assigned to another Church community.

\section{CONCLUSIONS AND IMPLICATIONS}

Through their ability to effect sustainable and holistic change due especially to their rootedness in the community and the social capital they help produce, faith-based organizations (FBOs) have long played a role in nation-building and international development. Moreover, those created and/or led by Christian leaders in particular are able to abide by and maintain their specific ethos or spiritual values, which has obvious impacts on contracts, workplace characteristics and behaviors, product or service offerings, resources and funding, relationships with clients, engagement with communities and citizens, etc., all of which in turn have certain implications for sustainability. 
Gawad Kalinga has been taking the lead role in strengthening social capital: it has sought to build a nation empowered by people with faith and patriotism, one that is made up of caring and sharing communities and dedicated to eradicating poverty, restoring human dignity, and encouraging stewardship by teaching members to act out that Biblical recommendation to be one's brother's keeper. In the case of the Focolare Movement, where helping the poor is not viewed as an optional appendage to prayer but as an expression of spirituality in other dimensions of social and economic life, the aim since the beginning has been to offer a global Christian response to the pressing problems of poverty and injustice by challenging the underlying ethos of business and finance. Finally, the Christian spirit of the Jesuit social apostolate was what enabled Rags2Riches to help the women of Payatas earn for themselves and live out their lives with greater human dignity.

Roman Catholic management education institutions, whose leaders are driven by social responsibility and the achievement of the common good, understand that it is their role to produce managers and business leaders who have the passion and commitment to help millions of Filipinos out of poverty and into lives of dignity and wellbeing (Teehankee, 2012). Faith and spirituality find their expression indeed in business leadership and operations, thereby enabling FBOs to have peculiar characteristics that make them especially successful and sustainable.

\section{REFERENCES}

Arnaldo, Z. 2008. Filipino weavers turn rags into riches. Calgary Herald (March): A18. Baker, B. 1996. A reverent approach to the natural world. Bioscience, 46(7): 475-478. Berger, J. 2003. Religious nongovernmental organizations: An exploratory analysis.

Voluntas: International Journal of Voluntary and Nonprofit Organizations, 14(1): 15-39.

Brillantes, A. B., \& Fernandez, M. T. 2011. Good governance, social quality, and active citizenship: Gawad Kalinga in the Philippines. International Journal of Social Quality, 1(2): 19-30.

Bruni, L. 2010. The entrepreneur and poverty. The Economy of Communion: $A$ New Culture, 16(31): 6-7.

Buckingham, H. 2012. Capturing diversity: A typology of third sector organisations' responses to contracting based on empirical evidence from homelessness services. Journal of Social Policy, 41(3): 569-589.

Caldwell, M. 2012. Placing faith in development: How Moscow's religious communities contribute to a more civil society. Slavic Review, 71(2): 261-287. 
Cantera, A. 2009. A fashionable love affair. McClatchy - Tribune Business News (April). Available at https://search.proquest.com/docview/456067885?account $\mathrm{id}=47253$ (accessed Jan. 22, 2018).

Chan, O. 2015. The profit sharing system study of San Jose KCM. Paper presented at the 9th International Symposium on Catholic Social Thought and Management Education. Manila: De La Salle University/Ateneo de Manila University.

Choudhury, M. A., Hossain, M. S., \& Solaiman, M. 2008. A well-being model of small-scale microenterprise development to alleviate poverty: A case study of Bangladesh village. International Journal of Sociology and Social Policy, 28(11/12): 485-501.

Clerkin, R. M., \& Grønbjerg, K. A. 2007. The capacities and challenges of faith-based human service organizations. Public Administration Review, 67(1): 115-126.

D'Amato, A., Henderson, S., \& Florence, S. 2009. Corporate social responsibility and sustainable business: A guide to leadership tasks and functions. North Carolina: Center for Creative Leadership.

Defourny, J. 2001. Introduction: From third sector to social enterprise. In C. Borzaga $\&$ J. Defourny (Eds.), The emergence of social enterprise: $1-28$. London / New York: Routledge.

Del Rosario, R. 2015. Keynote address. 9th International Conference on Catholic Social Thought and Business Education. Manila: Ateneo de Manila University.

Delbecq, A. L. 1999. Christian spirituality and contemporary business leadership. Journal of Organizational Change Management, 12(4): 345-349.

Ebaugh, H. R., Pipes, P., Chafetz, J., \& Daniels, M. 2003. Where's the religion? Distinguishing faith-based from secular social service agencies. Journal for the Scientific Study of Religion, 42(3): 411-426.

Evans, S., Raymond, C., \& Levine, D. 2014. Miami's third sector alliance for community well-being. Johns Hopkins University: Progress in Community Health Partnerships 8(2): 225-231.

Galera, G., \& Borzaga, C. 2009. Social enterprise: An international overview of its conceptual evolution and legal implementation. Social Enterprise Journal, 5(3): 210-228.

Gallagher, J., \& Buckeye, J. 2014. Structures of grace: The business practices of the economy of communion. New York: New City Press.

Ganzon, T. 2013. Bangko Kabayan: The experience of an economy of communion enterprise. Preparatory Seminar for the 9th International Conference on Catholic Social Thought and Business Education. Manila: De La Salle University. Gawad Kalinga. 2014. Homepage. Available at http://www.gk1world.com.

Gold, L. 2003. The roots of the Focolare Movement's economic ethic. Journal of Markets and Morality, 6(1): 143-159.

Goodin, R. 2003. Democratic accountability: The distinctiveness of the third sector. Archives Europeennes de Sociologie (European Journal of Sociology), 44(3): 359-396.

Graddy, E., \& Ye, K. 2006. Faith-based versus secular providers of social services: Differences in what, how, and where. Journal of Health and Human Services Administration, 29(3): 309-335. 
Habaradas, R. 2013. Corporate social initiatives in the Philippines: Experiences of four major corporations. Journal of Legal, Ethical and Regulatory Issues, 16(2): 1-16.

Habaradas, R., \& Aquino, M. L. 2010. Gawad Kalinga: Innovation in the city (and beyond). Manila: Angelo King Institute.

Hand, C. M., \& Crowe, J. L. 2012. Examining the impact of religion on environmentalism 1993-2010: Has the religious environmental movement made a difference? Electronic Green Journal, 1(34). Available at http://escholarship. org/uc/item/1z93165n.

Hardy, L., \& Ballis, H. 2013. Accountability and giving accounts: Informal reporting practices in a religious corporation. Accounting, Auditing and Accountability Journal, 26(4): 539-566.

Hefner, R. W. 2010. Religious resurgence in contemporary Asia: Southeast Asian perspectives on capitalism, the state, and the new piety. The Journal of Asian Studies, 69(4): 1031-1047.

Hicks, D. 2003. Religion in the workplace: Pluralism, spirituality, leadership. New York: Cambridge University Press.

Hill, P. J. 2000. Environmental theology: A Judeo-Christian defense. Journal of Markets \& Morality, 3(2): 158-172.

Hill, R. P. 2006. Distributive justice and Catholic faith-in-action: Lessons from consumer ethnographies. Urban Anthropology and Studies of Cultural Systems and World Economic Development, 35(2/3): 183-201.

Johnson, M. R. 2008. How spirituality impacts ethical leadership: A cross-case analysis of eleven corporate chief executive officers. Doctoral dissertation, University of San Diego School of Leadership and Education Sciences.

Kerlin, J. A. 2010. A comparative analysis of the global emergence of social enterprise. Voluntas, 21: 162-179.

Koveos, P., \& Randhawa, D. 2004. Financial services for the poor: Assessing microfinance institutions. Managerial Finance, 30(9): 70-95.

Kwarteng, C., \& Acquaye, H. 2011. The role of Ghanaian churches in the financial rehabilitation of the poor: Implications for re-visiting the social mission of religious institutions. Journal of Financial Services Marketing, 15: 309-319.

Ledgerwood, J. 1999. Microfinance handbook. Washington, DC: The World Bank. Loanzon, J. 2012. Generating social capital through fieldwork in economics education. Paper presented at the 8th International Symposium on Catholic Social Thought and Management Education. Ohio: University of Dayton.

Manalastas, P. T. 2007. A leader's values. In Doing good in business matters: CSR in the Philippines, Vol. 1: Frameworks: 342-351. Manila: Asian Institute of Management/De La Salle Professional Schools.

Meloto, A. 2009. Builder of dreams. Mandaluyong City: Gawad Kalinga Community Development Foundation.

Mitroff, I. I., \& Denton, E. A. 1999. A study of spirituality in the workplace. Sloan Management Review, 40(4): 83-92.

Moyer, J. M., Sinclair, A. J., \& Spaling, H. 2012. Working for God and sustainability: The activities of faith-based organizations in Kenya. Voluntas, 23: 959-992. 
Nevile, A. 2009. Values and the legitimacy of third sector service delivery organizations: Evidence from Australia. Voluntas, 20: 71-89.

Nielsen, C., \& Samia, P. M. 2008. Understanding key factors in social enterprise development of the BOP: A systems approach applied to case studies in the Philippines. Journal of Consumer Marketing, 25(7): 446-454.

Olasky, M. 1995. The tragedy of American compassion. Washington, DC: Regnery Gateway.

Pastores, K. A. 2010. Rags, riches and hotels: Father Javy Alpasa brings social entrepreneurship to Culion. The Manila Times (August). Available at https://search.proquest.com/docview/741127394? accountid=47253 (accessed Jan. 22, 2018).

Pelejo, M. A. 2012. Rags to Riches: An eco-ethical lifestyle. In S. S. Lam, L. Dela Cruz, D. J. Seah, \& G. H. Jacob (Eds.), Case collection on Philippines: Social entrepreneurship in Asia, working paper no. 2. Singapore: Asia Centre for Social Entrepreneurship \& Philanthropy.

Racelis, A. 2012. Ethics and governance issues in sustainability in Asia: Literature review and research proposals. Synergeia, 4(1): 155-174.

Sider, R., \& Unruh, H. R. 1999. No aid to religion? The Brookings Review, 17(2): $46-49$.

Sison, A. J., \& Palma-Angeles, A. 1997. Business ethics in the Philippines. Journal of Business Ethics, 16(14): 1519-1528.

Smith, A. 2010. The third sector, regeneration and sustainable communities. International Journal of Sociology and Social Policy, 30(1/2): 48-65.

Teehankee, B. 2012. Institutionalizing faith-based management education in a Catholic university. Journal of Catholic Higher Education, 31(2): 287-302.

Thaut, L. 2009. The role of faith in Christian faith-based humanitarian agencies: Constructing the taxonomy. Voluntas, 20: 319-350.

Traunmüller, R., \& Freitag, M. 2011. State support of religion: Making or breaking faith-based social capital? Comparative Politics, 43(3): 253-269. 